\title{
MODAL SOSIAL INKLUSIF DALAM JARINGAN KOMUNIKASI BENCANA
}

\author{
Damayanti Wardyaningrum \\ Program Studi Ilmu Komunikasi FISIP Universitas Al Azhar Indonesia \\ Kompleks Masjid Agung Al Azhar Jl. Sisingamangaraja Kebayoran Baru Jakarta Selatan \\ Telp (021) 7244456 email : damayanti@uai.ac.id
}

\begin{abstract}
This research aims at identifying inclusive social capital on communication network in the disaster preparedness of Merapi explosion in 2010 by operating concepts of communication network, social capital and disaster mitigation. The objects are local people in one of villages in Merapi mountain in Central Jawa. This research used positivistical paradigm using quantitative data and supported by qualitative data. The result shows that there are four inclusive social capitals in the communication network of Merapi: (1) relation with volunteer (2) relations with SAR team and NGO; (3) relation with local government and (4) and traditional relation with Yogyakarta Kingdom. In addition, the interpretaion of inclusive social capital is the existence of reciprocal feedback form local people. Inclusive social capital has facilitated information flow on disaster preparedness, influencing agent that has role as decision maker and supporting individual credibility to get access of resources and as identity builder and Inclusive social capital is recognition of local people. This research has not found yet Inclusive social capital in term of relation between local people and university institution who has many resources to build disaster preparedness.
\end{abstract}

Keyword : communication network, social capital, disaster phase mitigation

\begin{abstract}
Abstrak
Penelitian ini bertujuan untuk mengidentifikasi modal sosial inklusif apa saja yang terdapat pada jaringan komunikasi masyarakat pada fase kesiapsiagaan menghadapi bencana alam. Penelitian dilakukan di salah satu dusun yang rawan terhadap bencana gunung Merapi di Jawa Tengah. Konsep yang digunakan jaringan komunikasi, modal sosial dan mitigasi bencana. Penelitian menggunakan paradigma positivistik dengan metode pengumpulan data kuantitatif didukung data kualitatif. Hasilnya ditemukan empat modal sosial inklusif yang terdapat pada jaringan komunikasi masyarakat pada fase kesiapsiagaan bencana alam Merapi 2010 yaitu relasi dengan para relawan bencana, relasi dengan pemerintah daerah maupun propinsi, relasi dengan lembaga swadaya masyarakat dan relasi tradisional dengan keraton Yogyakarta. Selain itu intepretasi terhadap modal sosial inklusif adalah adanya timbal balik yang diperoleh warga dusun, modal sosial inklusif memfasilitasi aliran informasi tentang kesiapsiagaan menghadapi bencana erupsi, memengaruhi agen yang memiliki pengaruh penting dalam pengambilan keputusan, mendukung kredibilitas individu dalam memperoleh akses sumber daya untuk pertolongan dan sebagai pembangun identitas dan modal sosial inklusif merupakan pengakuan bagi warga dusun. Belum ditemukan modal sosial inklusif berupa relasi warga dusun dengan kalangan perguruan tinggi yang memiliki banyak sumberdaya untuk membantu kesiapsiagaan menghadapi bencana alam.
\end{abstract}

Kata kunci : jaringan komunikasi, modal sosial inklusif, fase kesiapsiagaan bencana.

\section{Pendahuluan}

Di seluruh wilayah Indonesia saat ini terdapat 3,9 juta penduduk yang beresiko terpapar bencana letusan gunung. Meskipun jumlah ini lebih kecil dibandingkan penduduk yang terpapar resiko bencana alam lainnya seperti tanah longsor (63 juta jiwa) dan gempa (148,8 juta jiwa) namun bencana letusan gunung api merupakan bencana alam yang paling merusak karena dalam dua tahun tahun terkahir yang mengakibatkan 12.404 rumah warga rusak berat (Kompas 7 Mei 2015). Bahkan 
sepanjang tahun 2015 terdapat ancaman letusan beberapa gunung aktif diantara 129 gunung berapi aktif yang ada. Meskipun belum sampai menimbulkan korban jiwa namun kerugian sosial ekonomi telah dialami oleh penduduk sekitar wilayah rawan bencana.

Bagi masyarakat yang berada diwilayah rawan bencana terdapat enam jenis kerentanan yang dihadapi dalam konteks sosial (David dan Alexander dalam Özerdem dkk:2006). Pertama, kerentanan ekonomi yaitu terdapat kondisi yang termarginalkan dalam memperoleh penghasilan selama terjadi bencana. Banyak penduduk yang kehilangan mata pencarian selama terjadi bencana. Kedua, kerentanan dalam bidang teknologi. Terdapat perbedaan akses terhadap teknologi antara level kelompok masyarakat. Antara kelompok kaya dan miskin, kelompok masyarakat yang tinggal dikota dan dipedesaan, negara kaya dan negara miskin, kelompok elit dan non elit. Ketiga, adanya kemunduran atau ketertinggalan, yaitu kerentanan terhadap kemungkinan timbulnya keadaan yang membuat masyarakat menjadi tertinggal dan harus membangun kembali kehidupannya. Hal ini memerlukam bantuan dari institusi seperti pemerintah dan bantuan dana. Keempat, perpindahan penduduk atau masyarakat yang sebelumnya tidak memiliki pengalaman terhadap tanda-tanda bahaya akan menimbulkan generasi baru yang rentan (newly-generated vulnerabilities). Kelima, kerentanan yang muncul sebagai akibat dari keputusan untuk menolak normanorma, aturan dan regulasi yang dianggap aman. Pada akhirnya, secara keseluruhan kondisi kerentanan muncul pada peristiwa bencana yang sering hadir dan dianggap sebagai bukan hal yang penting yang sebenarnya menciptakan kondisi bahaya dalam kehidupan secara umum.

Tabel 1. Letusan Gunung dan Dampaknya

\begin{tabular}{|c|c|c|c|}
\hline Gunung & Waktu Erupsi & Dampak Sosial Ekonomi & Sumber Artikel \\
\hline Slamet, Jawa Tengah & Maret-April & - & $\begin{array}{l}\text { Indopos, } 1 \text { April } 2015 \text { Gempa } \\
\text { Tremor Terekam }\end{array}$ \\
\hline $\begin{array}{l}\text { Karangetang, } \\
\text { Siau Sulawesi Utara }\end{array}$ & April - Mei & - & $\begin{array}{l}\text { Kompas, } 22 \text { Mei 2015, Karangetang } \\
\text { dan Lokon Terus Aktif }\end{array}$ \\
\hline $\begin{array}{l}\text { Lokon, Tomohon } \\
\text { Sulawesi }\end{array}$ & April - Mei & - & $\begin{array}{l}\text { Kompas, } 22 \text { Mei 2015, Karangetang } \\
\text { dan Lokon Terus Aktif }\end{array}$ \\
\hline $\begin{array}{l}\text { Sinabung, Sumatera } \\
\text { Utara }\end{array}$ & $\begin{array}{l}\text { sejak 2010- saat } \\
\text { ini }\end{array}$ & $\begin{array}{l}\text { Lebih dari } 3.000 \text { jiwa mengungsi, } \\
\text { biaya relokasi }+/-700 \mathrm{~m} \text {, lahan } \\
\text { pertanian rusak }\end{array}$ & $\begin{array}{l}\text { Kompas, } 7 \text { Juni 2015, Warga } \\
\text { Kembali Memasuki Zona Bahaya }\end{array}$ \\
\hline Raung, Jawa Timur & Juli & $\begin{array}{l}\text { Penutupan operasional tiga } \\
\text { bandara pada saat musim puncak. }\end{array}$ & $\begin{array}{l}\text { Kompas, } 2 \text { Juli 2015, Warga } \\
\text { Diminta Jauhi Puncak }\end{array}$ \\
\hline Welirang, Jawa Timur & Juni & - & $\begin{array}{l}\text { Kompas, } 2 \text { Juli 2015, Aktivitas } \\
\text { Gunung Welirang }\end{array}$ \\
\hline $\begin{array}{l}\text { Gamalama,Ternate } \\
\text { Maluku Utara }\end{array}$ & Juli & $\begin{array}{l}775 \text { warga mengungsi dan } \\
\text { terserang penyakit, lahan } \\
\text { pertanian rusak }\end{array}$ & $\begin{array}{l}\text { Kompas, } 29 \text { Juli 2015, Asap keluar } \\
\text { Melalui Rekahan Dekat Puncak }\end{array}$ \\
\hline $\begin{array}{l}\text { Colo, Kab Tojo Una } \\
\text { Una Sulawesi Tengah }\end{array}$ & Juni & - & $\begin{array}{l}\text { Kompas, } 22 \text { Juni 2015, Status } \\
\text { Gunung Colo Masih Waspada }\end{array}$ \\
\hline
\end{tabular}


Permasalahan berikutnya yang penting terkait dengan mitigasi bencana adalah mengenai peran warga lokal sebagai bagian dalam proses mitigasi bencana. Persoalan bencana bukan hanya mengenai berapa jumlah jiwa dan harta benda yang dapat diselamatkan namun mitigasi bencana penting untuk lebih terfokus pada bagaimana penduduk dan harta benda dapat terhindar dari bencana. Salah satu unsur yang membantu keefektifan penanganan bencana adalah jika ada kerjasama dari seluruh komponen anggota masyarakat berikut kerjasama dengan berbagai pihak lain yang memberikan kontribusi bagi penyelesaian permasalahan masyarakat lokal saat terjadi bencana. Jika meninjau beberapa penelitian-penelitian terdahulu berikut ini ditemukan peran modal sosial dalam penanganan bencana.

Hasil penelitian Tim Universitas Gadjah Mada (2012) menemukan sebuah model alternatif untuk dikembangkan berdasarkan pemetaan secara umum tentang korban bencana dan kelanjutan kehidupannya. Terdapat tiga faktor yang menunjang hal tersebut yaitu ketersediaan modal sumberdaya manusia, kapasitas dari modal sosial dan suport komunitas dalam mempertahankan keberlanjutan lingkungan. Selain itu Budiarti \& Riskha (2012) juga menyimpulkan dari penelitian tentang bencana Merapi bahwa faktor penentu kesuksesan proyek pengelolaan pemulihan bencana pasca letusan Merapi adalah persiapan untuk pengurangan resiko bencana, kordinasi dan kolaborasi, partisipasi dan keselarasan dengan masyarakat, kemampuan dan dedikasi dari pelaksana.

Sementara itu hasil penelitian Lestari dkk (2010) juga menekankan pentingnya kajian manajemen komunikasi bencana terutama pada saat tanggap darurat guna mempercepat proses konstruksi dan rehabilitasi. Proses manajemen komunikasi bencana dilakukan melalui tahap perencanaan, pelaksanaan, kordinasi dan evaluasi. Dari penelitian-penelitian terdahulu maka dapat penulis simpulkan bahwa manajemen komunikasi menyatukan berbagai modal sosial yang dimiliki oleh masyarakat dalam penanganan bencana. Peran modal sosial juga dapat dilihat dari aspek yang luas yaitu bahwa dalam penanganan bencana dari penelitian Martin R. Degg dan K. David (2005) yang berhasil mengidentifikasi bahwa saat ini adanya kemajuan yang sangat berarti antara dimensi fisik dan sosial tentang kewaspadaan dan pendekatan baru dalam memahami dan mengurangi resiko kerawanan bencana. Sehingga diperlukan peningkatan riset-riset yang lebih inklusif, menggunakan pendekatan budaya dan strategi yang menyatukan masyarakat pada tingkat lokal, nasional dan internasional dalam penanganan mitigasi bencana.

Beberapa penelitian dalam peristiwa bencana alam yang menggunakan jaringan sosial juga melengkapi penelitian terkait modal sosial. Jaringan sosial yang ada di masyarakat dapat dimanfaatkan oleh pemimpin untuk mengirimkan pesan dan menerima informasi serta melakukan program intervensi yang efektif pada keseluruhan fase bencana. Respon 
masyarakat dan proses adaptasi terhadap bencana serta analisis prediksi bencana dan penanganannya dapat dilakukan dengan mempelajari struktur jaringan dan sosiodemografik masyarakat. Selain itu jaringan sosial memiliki kontribusi besar terhadap kekuatan individu dan kelompok untuk bertahan dan mampu melewati masa genting pada fase-fase bencana dan memberikan manfaat yang efektif untuk pertolongan. Melalui jaringan sosial juga dapat diketahui formasi bantuan pertolongan yang terdesentralisasi dan menawarkan program pelatihan penanganan bencana yang sesuai. (Varda,2008; Ozerdam \& Jacoby,2006:61; Magsino,2009: 10-31).

Dengan meninjau beberapa penelitian terdahulu serta mempertimbangkan semakin tingginya kompleksitas persoalan bencana maka kajian jaringan komunikasi memiliki berkontribusi penting dalam mengkaji persoalan sosial bencana alam. Dengan kajian jaringan komunikasi sebagai aplikasi dari jaringan sosial yang diperdalam dengan kajian modal sosial dapat memberikan gambaran yang semakin lengkap guna memberikan alternatif bagi penanganan bencana secara lebih komprehensif.

Adapun bentuk bentuk modal sosial menurut Coleman (2011:422) diantaranya adalah kewajiban dan ekspektasi, potensi informasi, norma dan sangsi efektif, relasi wewenang serta organisasi sosial yang dapat disesuaikan. Sehingga jika dikaitkan dengan konteks peristiwa bencana maka bentuk modal sosial yang diperlukan adalah adanya relasi wewenang serta potensi informasi. Selanjutnya kedua komponen tentang informasi dan relasi dapat diperoleh dengan mengidentifikasi melalui jaringan komunikasi yang ada dalam masyarakat. Karena elemen utama dari sebuah jaringan komunikasi adalah aktor dan relasi dimana didalamnya dapat diperoleh bagaimana informasi mengalir dalam jaringan komunikasi.

Modal sosial menurut Lin (1999:3-4) merupakan investasi dalam hubungan sosial yang diharapkan dapat memberikan imbal balik. Definisi yang bersifat umum inimemiliki beberapa elemen didalamnya. Pertama memfasilitasi aliran informasi. Kedua, ikatan sosial tersebut dapat mempengaruhi agen yang memiliki peran penting dalam pengambilan keputusan. Ketiga, sumber daya dalam ikatan sosial akan mendukung kredibilitas individu atau organisasi dalam memperoleh akses terhadap sumber daya melalui jaringan atau modal sosialnya. Keempat, relasi sosial akan membangun sebuah identitas dan adanya pengakuan.

Dengan demikian dapat disimpulkan bahwa modal sosial dapat memberikan keuntungan bagi individu maupun kelompok dalam hubungannya dengan pihak lain, dalam pemenuhan sumberdaya yang saling melengkapi satu sama lain, menjamin kredibilitas seseorang maupun kelompok sehingga mempermudah keyakinan pihak lain untuk bekerjasama, menunjukkan identitas dan pengakuan. Imbal balik yang diperoleh dari modal sosial tentunya dengan melihat kepentingan setiap anggota dalam modal sosial tersebut.

Sementara itu jaringan komunikasi sebagai kajian yang terkait dengan modal 
sosial memberikan analisis yang lebih terinci mengenai relasi dan aktor orangorang dalam suatu jaringan tertentu. Analisis jaringan komunikasi pada dasarnya adalah penerapan dari analisis jaringan sosial pada bidang komunikasi (Eriyanto,2014:23). Sedangkan Rogers dan Kincaid (1981:82) mendefinisikan metode jaringan sebagai suatu metode riset untuk mengidentifikasi struktur komunikasi dalam sebuah sistem, dimana data relasional tentang aliran komunikasi dianalisis dengan menggunakan relasi interpersonal sebagai unit analisisnya. Dari definisi tersebut maka penekanannya adalah pada struktur komunikasi yang mencakup aliran komunikasi dan data relasi.

Metode jaringan komunikasi memiliki kelebihan dibanding metode survey antara lain karena jaringan komunikasi menggambarkan suatu proses sehingga bisa menjelaskan proses terbentuknya fenomena atau peristiwa komunikasi. Studi jaringan komunikasi menekankan pada posisi aktor dan kekuatan aktor dalam struktur sosial dilakukannya perbandingan aktor dalam jaringan. Selain itu melalui pola jaringan komunikasi dapat diketahui bagaimana tahapan suatu informasi dapat tersebar dan siapa saja yang berperan penting dalam penyebaran informasi (Eriyanto,2014:14-15).

Dari beberapa penelitian terdahulu nampak tentang pentingnya modal sosial membantu dalam peristiwa kebencanaan. Selain itu dari penelitian pendahuluan yang telah dilakukan tentang jaringan komunikasi pada seluruh fase mitigasi bencana (Wardyaningrum, 2016) maka perlu dilakukan pengembangan tentang jaringan komunikasi pada masyarakat di wilayah rawan bencana melalui perspektif modal sosial. Bahwa salah satu fase penting dalam mitigasi bencana adalah pada fase kesiapsiagan, dimana biasanya fokus masyarakat ada pada fase tanggap darurat yang berupaya menyelamatkan korban dan harta benda maka dengan lebih menekankan pada fase kesiapsiagaan diharapkan masyarakat akan terhindar dari bencana dan memperkecil resiko. Dengan demikian maka dapat dirumuskan permasalahan penelitian sebagai berikut. Pertama, bagaimana gambaran jaringan komunikasi pada fase kesiapsiagaan bencana ? Kedua, modal sosial inklusif apa saja yang terdapat pada jaringan komunikasi masyarakat dalam kesiapsiagaan menghadapi bencana alam ? Tujuan penelitian ini adalah untuk mengidentifikasi gambaran tentang jaringan komunikasi pada fase kesiapsiagaan bencana serta apa saja modal sosial inklusif yang terdapat dalam jaringan komunikasi masyarakat komunikasi pada fase kesiapsiagaan bencana.

Selain memberikan manfaat bagi pengembangan ilmu sosial, penelitian ini diharapkan memberikan manfaat praktis bagi pengembangan modal sosial terutama yang inklusif guna mendukung masyarakat baik secara individu maupun kelompok untuk keperluan kesiapsiagaan menghadapi bencana alam.

\section{Jaringan Komunikasi}

Jaringan komunikasi adalah penggunaan analisis jaringan sosial dalam bidang ilmu komunikasi (Eriyanto,2014:23) atau dapat dikatakan bahwa analisis jaringan 
komunikasi pada dasarnya adalah penerapan dari analisis jaringan sosial (Social Network Analysis) pada bidang komunikasi. Rogers dan Kincaid (1981: 82) mendefinisikan metode jaringan sebagai suatu metode riset untuk mengidentifikasi struktur komunikasi dalam sebuah sistem, dimana data relasional tentang aliran komunikasi dianalisis dengan menggunakan relasi interpersonal sebagai unit analisisnya.Dari definisi tersebut maka penekanannya adalah pada struktur komunikasi yang mencakup aliran komunikasi dan data relasi.

Melalui pola jaringan komunikasi dapat diketahui bagaimana tahapan suatu informasi dapat tersebar dan siapa saja yang berperan penting dalam penyebaran informasi. Sebuah studi pada jaringan pengusaha menemukan bahwa komunikasi dua tahap dapat terwujud dalam dua jenis meknisme jaringan yang berbeda. Pertama, penularan informasi terjadi melalui pemuka pendapat kedalam kelompok. Kedua,penularan informasi terjadi diantara anggota- angota kelompok yang posisinya setara. Pemuka pendapat dalam jaringan dapat berperan sebagai perantara (brokers) seperti dalam jaringan bisnis karena memiliki akses dengan pihak luar (Burt, 1999:65).

Dengan demikian maka bahwa jaringan komunikasi yang didalamnya berisi berbagai macam informasi sesungguhnya merupakan sebuah sistem yang bersifat kompleks.Monge dan Contractor (2003:85) mengemukakan bahwa dari teori sistem yang berevolusi fenomena yang statis menjadi dinamis, kompleks dan beradaptasi.
Teori ini juga melandasi organisasi jaringan komunikasi yang saat ini dapat dilihat sebagai sebuah sistem yang kompleks yang terkelola sendiri, yang mengalami perubahan dari perilaku interkoneksi yang sebelumnya diatur oleh agen-agen. Jaringan sendiri dapat ditinjau sebagai sebuah properti yang saling tergantung sama lain, bersifat spesifik, mengalami perubahan pada atributnya serta mengalami perubahan koneksi dengan jaringan lain beserta anggotanya didalam lingkungan tempat jaringan tersebut berada.

Uraian tersebut menurut peneliti sejalan dengan konsep jaringan yang dikemukakan oleh Francis Fukuyama yang mengemukakan penting bahwa jaringan memberikan saluran-saluran alternatif bagi aliran informasi melalui dan kedalam sebuah organisasi.Sehingga jaringan yang didefinisikan sebagai kelompok-kelompok yang berbagi norma-norma atau nilai-nilai informal adalah hal yang penting.Karena seringkali hierarki bisa dianggap kurang adaptif. Sistem-sistem kontrol formal jauh lebih tidak fleksibel dibandingkan sistem kontrol informal (Fukuyama, 2000:332).

Struktur jaringan yang berhubungan dengan pemusatan suatu jaringan adalah sentralitas yang merujuk bagaimana posisi aktor dalam keseluruhan jaringan. orang-orang yang berada di posisi sentral menjadi sangat penting, karena banyak orang yang ingin mengetahui siapa saja yang berada di posisi sentral dan siapa saja yang menduduki posisi sebagai pemimpin. Seberapa sentral seorang aktor dalam suatu jaringan, siapa aktor yang 
paling menonjol dan paling menentukan dalam jaringan. Dengan menduduki lebih banyak posisi sentral, seorang pemimpin akan lebih besar peluangnya untuk mencari berbagai sumberdaya (teman, keahlian dan sebagainya) dan lebih mudah dalam memperoleh akses informasi atau dukungan dari jaringan sosial. Selain itu anggota yang terdapat dalam posisi sentral dapat memberikan pengaruh yang signifikan terhadap kecepatan perubahan perilaku. (Carolan dalam Eriyanto, 2014:199: Borgatti \& Everett dalam Valente, 2010:17)

\section{Modal Sosial}

Penjelasan Nan Lin tentang konsep modal sosial memfokuskan modal sosial sebagai sebuah asset dalam suatu jaringan. Studi yang dilakukan berhasil mengemukakan tentang faktor-faktor apa saja yang menentukan adanya ketidakseimbangan dalam modal sosial dan faktor apa saja yang dapat mengembalikan investasi modal sosial (Lin, Cook \& Burt, 2001:3) Beberapa studi tentang modal sosial antara lain yang ditemukan Lin tentang modal sosial juga sejalan dengan Granoveter yang menekankan bahwa studi-studi tentang jaringan sosial menekankan betapa pentingnya peran penghubung (bridges) pada suatu jaringan dalam menyalurkan informasi dan mengalirkan pengaruh pada individu maupun kelompok dalam jaringan (Lin, Cook \& Burt, 2001 :10). Selain itu modal sosial memberikan keuntungan dalam memperoleh jaringan dan kelompok (perspektif individu), atau memberikan keuntungan untuk menjaga aset sosial dan memperoleh peluang (perspektif kelompok) (Lin:1999). Modal sosial dapat ditinjau baik dari level mikro maupun level makro yang keduanya memberikan keuntungan bagi setiap pihak dengan saling berhubungan satu sama lain.

Konsep lain tentang modal sosial disampaikan oleh Coleeman dalam Marfai dkk (201;603) yang menjelaskan bahwa modal sosial (social capital) merupakan kemampuan masyarakat untuk bekerjasama, demi untuk mencapai tujuan bersama-sama didalam berbagai kelompok dan organisasi. Tiga jenis tipologi utama menurut Woolock dalam Marfai dkk (2013:65) yaitu social capital bonding (modal sosial terikat), social capital bridging (modal sosial menjembatani), dan social capital linking (modal sosial menghubungkan). Social capital bonding biasanya ditunjukkan melalui nilainilai yang dianut, kultur, persepsi, dan tradisi atau adat istiadat (custom) yang disepakati. Social capital bridging dalam hal ini berupa institusi maupun mekanisme merupakan ikatan sosial yang timbul sebagai reaksi atas berbagai macam karakteristik kelompoknya. Jembatan sosial tersebut dapat muncul karena adanya berbagai kelemahan sehingga memutuskan untuk membangun kekuatan diluar dirinya. Sedangkan social capital linking dapat berupa hubungan atau jaringan.

Modal sosial dapat dibagi menjadi dua menurut Field (2011:106-107). Pertama, modal sosial yang mengikat (atau ekslusif) didasarkan pada hubungan keluarga, teman dekat, dan kelompok akrab lainnya; 
mengikat kedalam dan mengikat orang lain dari posisi sosial serupa dan hal ini cenderung meneguhkan identitas ekslusif dan kelompok homogen. Kedua modal sosial yang menjembatani (inklusif) menghubungkan orang pada kenalan-kenalan jauh yang bergerakpadalingkaran yang berbeda dengan lingkaran mereka sendiri; hal ini cenderung membangun identitas yang lebih luas dan resiprositas yang lebih banyak dibandingkan meneguhkan pengelompokkan sempit. Putnam mempercayai bahwa modal sosial yang mengikat baik untuk "disinggahi' dan modal sosial yang menjembatani adalah sesuatu yang krusial untuk dijalani.

Dari kedua bentuk modal sosial tersebut dapat dilihat bahwa pada modal sosial yang eksklusif bermanfaat untuk mempertahankan nilai-nilai. Seperti nilai budaya, nilai-nilai tradisional dan kesepakatan kelompok dan sebagainya. Namun anggota dari kelompok dengan bentuk modal sosial eksklusif cenderung tidak mengalami perubahan, memiliki pengetahuan yang terbatas hanya berasal dari anggota kelompoknya saja dan tidak informasi yang diperoleh tidak bertambah atau merubah nilai yang dianut masyarakatnya. Sementara untuk modal sosial yang sifatnya inklusif memberikan manfaat terhadap masuknya nilai nilai baru dari luar, dapat menerima hal-hal baru sehingga menambah informasi yang diperoleh saat ini. Namun dengan modal sosial ini nilai-nilai lama yang dianut dapat berubah, masuknya nilai baru dapat mengikis nilai-nilai lama, identitas asli kelompok dapat memudar atau berubah sama sekali. Modal sosial juga menentukan bagaimana nilai-nilai yang ada dapat dipertahankan, tetap seimbang, atau tidak hilang.

Sementara itu Coleman (2011:415) mengutip dari Loury menguraikan bahwa kumpulan sumber yang melekat dalam relasi keluarga dan dalam organisasi sosial komunitas dan yang bermanfaat untuk perkembangan kognitif dan sosial anakanak atau pemuda. Sumber-sumber ini berbeda untuk orang yang berbeda dan dapat memberikan keuntungan penting untuk perkembangan modal manusia dan orang dewasa. Modal sosial tercipta ketika ada relasi antara orang yang mengalami perubahan dengan cara-cara yang memudahkan tindakan.

Penjelasan lain mengenai modal sosial dikemukakan oleh Lawang (2005:30) yang menggunakan istilah kapital sosial. Kata sosial dalam kapital sosial menurut pandangannya harus bersifat positif. Ada dua alasan yaitu bahwa pertama kapital sosial harus mendorong adanya pertumbuhan ekonomi, jika tidak demikian maka bukan disebut capital kedua kapital sosial harus mampu membuat pertumbuhan itu berdampak pada peningkatan kesejahteraan sosial yang meluas kemasyarakat. Aspek ini memang lebih menekankan pada hubungan antara efektifitas dan efisiensi sedangkan menurut Granoveter yang dikutip oleh Lawang melihat aspek sosial dari aspek struktural. Dimana kapital sosial tidak berdiri sendiri namun tertambat (embedded) dalam struktur sosial. Yang dimaksud struktur 
sosial para ahli umumya menunjuk pada hubungan (relation), jaringan (network), kewajiban, harapan yang menghasilkan dan dihasilkan oleh kepercayaan (trust) dan sifat dapat dipercaya (trustworthiness), yang berkembang diantara orang-orang yang berhubungan. Dengan demikian konsep ini sejalan dengan pendapat Fukuyama (2000:359) yang menyebutkan bahwa ada tiga alasan pentingnya hirerarki pada social capital. Pertama, kita tidak bisa menerima begitu saja eksistensi jaringan dan social capital yang mendasarinya dan dimana jaringan itu tidak eksis, hierarki dapat menjadi satu-satunya bentuk organisasi yang mungkin. Kedua, hirerarki seringkali secara fungsional penting bagi organisasi untuk mencapai tujuannya. Ketiga, masyarakat secara alami suka mengorganisasi diri mereka secara hierarkis,

Sementara itu konsep-konsep inti yang terdapat dalam kapital sosial yang dikemukakan oleh Lawang (2005:45) serta mengutip pendapat Coleman, Putnam dan Fukuyama maka unsur-unsur dari modal sosial yang terdiri dari kepercayaan, norma, dan jaringan. Uraian Bourdieu dan Wacquant yang dikutip oleh Mongie dan Contractor (2011:143) menyebutkan bahwa modal sosial merupakan sejumlah sumberdaya, baik dalam bentuk nyata atau virtual, yang menumbuhkan nilai pada diri individu atau kelompok berdasarkan adanya kepemilikan sebuah jaringan yang bertahan lama atau kurang lebih hubungan yang terinstitusionalisasi dari sebuah perkenalan atau pengenalan.
Penekanan pada teori tersebut adalah adanya kumpulan sejumlah sumber daya jaringan yang bertahan lama atau terinstitusionalkan dan membedakan antara modal sosial dan modal manusia (human capital). Bahwa modal manusia (human capital) lebih merepresentasikan atribut atau karakteristik yang ada pada diri setiap orang seperti intelegensi, daya tarik dan prestis. Lebih jauh diuraikan oleh Mongie dan Contractor bahwa modal sosial tumbuh dari hubungan-hubungan seperti halnya yang tertambat dalam jaringan komunikasi

Premis yang dikemukakan Lin (1999:34) mengenai modal sosial secara singkat adalah investasi dalam hubungan sosial yang diharapkan dapat memberikan imbal balik. Definisi yang bersifat umum ini memiliki beberapa elemen didalamnya. Pertama memfasilitasi aliran informasi. Kedua, ikatan sosial tersebut dapat mempengaruhi agen yang memiliki peran penting dalam pengambilan keputusan. Ketiga, sumber daya dalam ikatan sosial akan mendukung kredibilitas individu atau organisasi dalam memperoleh akses terhadap sumber daya melalui jaringan atau modal sosialnya. Keempat, relasi sosial akan membangun sebuah identitas dan adanya pengakuan.

\section{Bencana dan Fase Bencana}

Dalam pasal 1 UU no 24 tahun 2007 tentang Penanggulangan Bencana, yang dimaksud dengan bencana adalah "peristiwa atau rangkaian peristiwa yang mengancam dan menganggu kehidupan dan penghidupan masyarakat yang disebabkan baik oleh faktor alam, faktor non alam maupun faktor manusia sehingga mengakibatkan timbulnya 
korban jiwa manusia, kerusakan lingkungan, kerugian harta benda dan dampak psikologis". Dalam UU yang sama juga ditetapkan tiga jenis bencana: bencana alam, bencana non alam, dan bencana sosial. Sedangkan bencana alam adalah bencana yang diakibatkan oleh peristiwa atau serangkaian peristiwa yang disebabkan oleh alam antara lain berupa gempa bumi, tsunami, gunung meletus, banjir, kekeringan, angin topan, dan tanah longsor. Sehingga suatu peristiwa dianggap bencana jika peristiwa itu menimbulkan kerusakan, menimbulkan gangguan pada kehidupan, penghidupan, dan fungsi masyarakat yang mengakibatkan korban dan kerusakan melampaui kemampuan masyarakat setempat untuk mengatasinya dengan sumber daya yang dimiliki. Dapat disimpulkan bahwa kemampuan masyarakat dalam menghadapi bencana adalah hal yang penting.

Sylves (2008:26) mengemukakan bahwa dalam mitigasi tercakup keputusan untuk melakukan apa dan dimana terkait masalah kesehatan, keamanan dan kesejahteraan dari masyarakat yang telah ditentukan dan dilaksanakan sebagai program pengurangan resiko. Hal ini merupakan tindakan yang berkelanjutan untuk mengurangi resiko terhadap jiwa dan harta benda serta dampaknya. Berikutnya hal lain yang penting terkait dengan mitigasi adalah perhitungan efektifitas biaya yang dikeluarkan dengan pengurangan resiko yang akan terjadi termasuk kemungkinan resiko fisik dan sosial dimasa yang akan datang.

Claude Gilbert menyodorkan ringkasan konsep tentang bencana (Porfiriev dalam Quarantelli, 1998) dalam tiga paradigma yaitu. Pertama, bencana adalah merupakan hasil atau akibat dari suatu tekanan eksternal. Kedua, akibat dari kerentanan sosial dan ketiga akibat dari ketidakpastian. Konsep ini masih senada dengan Pelanda yang dikutip dari sumber yang sama mengintepretasikan bencana sebagai berikut. Pertama, bencana adalah akibat dari kondisi sosial dan lingkungan yang buruk, kedua, bencana merupakan akibat dari tekanan kolektif dari sebuah komunitas, dan ketiga adalah adanya perbedaan dalam kapasitas untuk menangani kerusakan dan akibat negatif yang ditimbulkan. Pendapat lain dikemukakan oleh Maloney dan Cappola (2009:48-49) tentang bencana :

Disaster are measured in terms of lives lost, injuries, sustained, property damaged or lost, and environment degradation. These consequences manifest themselves through direct and indirect means and can be tangible or intangible.

Beberapa ahli sosial menekankan pemahaman tentang bencana sebagai sebuah konstruksi sosial. Bagi para ahli tersebut melihat bencana sebagai dampak dari proses sosial atau konsekuensi sosial yang menghasilkan bahaya, atau meningkatkan kerentanan dari sebuah sistem sosial dari dampak suatu bahaya (Porfiriev dalam Quarantelli,1998:46).

Selanjutnya dari kajian konsep dan pragmatis tentang bencana Quarantelli mencoba memberikan definisinya:

A state/condition destabilizing the social system that manifest itself in malfunctioning or disruption of connection and communications between its elements or social units (communities, social groups, andindividuals), partialortotaldetruction/ demolition, physical and psychological overload 
suffered by some of these elements; thus, making it necessary to take extraordinary or emergency countermeasures to reestablish stability.

Carter (2008) juga memiliki uraian yang melengkapi bahwa berdasarkan pengalaman penanganan bencana didunia terdapat kesimpulan bahwa respon yang efektif terhadap bencana sangat tergantung pada dua faktor yaitu informasi dan sumberdaya. Tanpa kedua faktor ini perencanaan mitigasi bencana yang disusun dengan baik, managemet yang terkordinasi dan staf yang handal akan menjadi sia-sia.

Dengan menggunakan berbagai macam sistem, dan kolaborasi antara masyarakat, pemerintah, lembaga non pemerintah, pihak swasta akan meningkatkan kemampuan sistim komunikasi dalam mencapai target sasaran masyarakat, Kelompok-kelompok masyarakat yang harus memiliki kesadaran dalam perencanaan peringatan dini termasuk individu adalah : keluarga, sekolah, lingkungan kerja, tempat umum, kelompok orang cacat, masyarakat yang menggunakan bahasa asing, kelompok masyarakat tidak terdidik dan kelompok masyarakat miskin.

Carter (2008:29) membagi bencana dalam 5 segmen yaitu :Prevention, Mitigation, Preparedness, Response dan Recovery. Pada segmen awal yaitu pencegahan (prevention), fokus perhatiannya adalah pada hal-hal akan mengenai pentingnya upaya pencegahan, wilayah yang perlu menjadi perhatian untuk dilakukan pencegahan, pendekatan yang positif melalui upaya pencegahan dan sumberdaya apa saja yang diperlukan untuk pencegahan.
Pada segmen mitigasi (mitigation), tindakan yang dilakukan biasanya merupakan program yang spesifik untuk mengurangi dampak dari bencana pada suatu bangsa atau komunitas.Pemahaman tentang mitigasi lebih luas adalah implikasi dampak dari bencana, namun demikian dampak tersebut dapat dimodifikasi atau dikurangi dengan tindakan yang sesuai. Beberapa tindakan atau program terkait dengan mitigasi antara lain: regulasi pemanfaatan wilayah, regulasi tentang keamanan untuk bangunan tinggi, kontrol terhadap materi hazard, keamanan sistem transportasi darat, laut dan udara; pembangunan sistem untuk melindungi instalasi listrik dan alat komunikasi vital, pembangunan infrastruktur seperti misalnya pembangunan jalan bebas hambatan yang tidak berdekatan dengan wilayah rawan bencana.

Segmen ketiga adalah kesiapsiagaan (preparedness). Pada fase ini terdapat beberapa hal penting yang diperlukan sebagai upaya peringatan dini yaitu : deteksi dini yang dilakukan seawal mungkin tentang akan datangnya bencana, proses peringatan dini yang harus dilakukan oleh pihak yang memiliki wewenang sehingga menghindari informasi yang tidak perlu, adanya rantai transmisi informasi yang efektif, pengambilan keputusan setelah adanya peringatan dini, dan penyebaran informasi peringatan dini ke publik secara tepat (Carter, 2008:238-243). Dari banyak pengalaman mitigasi bencana reaksi awal terhadap peringatan dini bencana dapat menyelamatkan nyawa dan harta benda. 
Pada periode tanggap darurat (response) aspek emergensi yang perlu diperhatikan pada fase tanggap darurat adalah : a) penyelamatan dan pertolongan terhadap korban b) pengungsian korban ke wilayah lain c) penyediaan tempat penampungan sementara yang layak d) penyediaan makan, baik distribusi dan persediaan stok bahan pangan e) pembukaan akses jalan melalui darat udara atau laut termasuk pendaratan helikopter f) ketersediaan alat komunikasi g) ketersediaan air bersih h) ketersedian barang-barang kebutuhan untuk pengungsi h) sarana kesehatan dan sanitasi, tenaga medis i) ketersediaan informasi publik. Tersedianya informasi bagi komunitas tentang apa yang harus dilakukan j) jaminan keamanan k) konstruksi untuk bangunan yang mendapatkan prioritas tertinggi 1)jaminan untuk dukungan moral bagi korban. Segmen recovery, merupakan proses pemulihan yang dapat berlangsung lama bahkan bisa mencapai waktu antara 5-10 tahun atau lebih. Pemulihan pasca bencana biasanya melibatkan berbagai aspek seperti restorasi dan rekonstruksi. Dalam melaksanakan program pemulihan pasca bencana keterlibatan berbagai institusi sangat diperlukan antara lain seperti pemerintah yang memiliki otoritas dalam hal perencanaan membangun maupun pemerintah yang menangani bencana baik pusat maupun lokal termasuk institusi yang menyediakan pendanaan (Carter, 2008:288).

Maloney dan Cappola (2009:53-55) mengemukakan bahwa manajemen bencana yang komprehensif pada masyarakat modern didasarkan atas empat komponen yaitu
(1) mitigasi (2) kesiapan (3) respon dan (4) pemulihan. Mitigasi mencakup upaya pengurangan atau penghapusan baik salah satu atau kedua hal tersebut terhadap dari bahaya resiko (baik masih berupa kemungkinan atau akibat yang ditimbulkan). Kesiapan adalah cara untuk melindungi orang-orang yang beresiko terdampak bencana dengan cara meningkatkan kapasitasnya untuk dapat bertahan atau memperkecil kerugian ekonomi. Respon dicirikan dengan tindakan guna mengurangi atau menghapuskan dampak bencana yang mungkin timbul atau sudah terjadi. Kates dan Pijawka yang dikutip oleh Smith dan Wenger dalam Rodriguez dkk (2006:235) bahkan membagi lagi fase pemulihan bencana menjadi beberapa bagian yaitu periode emergensi, periode restorasi, periode pemindahan dan rekonstruksi serta peringatan, kemajuan, dan periode pembangunan rekonstruksi. Hal ini menunjukkan bahwa periode pemulihan merupakan fase yang prosesnya panjang dan penting untuk mempersiapkan masyarakat melanjutkan kehidupan yang baru serta mempersiapkan diri terhadap adanya kemungkinan bencana berikutnya.

Keberhasilan mitigasi bencana dalam peristiwa erupsi gunung berapi sangat bergantung kepada ketersediaan informasi. Informasi tersebut diantaranya adalah mengenai aktivitas gunung api seperti mengenai karakter, perilaku dan sejarah letusan gunung api guna keperluan prediksi waktu terjadinya letusan, jenis bahaya yang akan ditimbulkannya dan daerah-daerah yang potensial terkena bahaya letusan sebuah gunung api. 


\section{Metode Penelitian}

Penelitian dilakukan di dusun Kalitengahkidul, Glagahharjo Sleman Yogyakarta. Hingga saat ini proses pemulihan pasca bencana Merapi 2010 masih terus berlangsung karena warga dusun bersikeras untuk kembali ke wilayah tersebut meskipun sudah dinyatakan sebagai zona merah oleh pemerintah. Sebagai salah satu gunung berapi yang teraktif didunia, maka setiap tahun muncul ancaman erupsi Merapi yang harus dihadapi warga dusun. Letusan Merapi pada tahun 2010 merupakan yang terbesar dalam 1.000 tahun terakhir dan penduduk yang dievakuasi mencapai 380.000 jiwa (Kompas 15 Februari 2015). Ancaman erupsi Merapi dan banjir lahar dingin yang masih berlangsung hingga saat ini dan sebagai salah satu wilayah yang terparah dilanda bencana pada erupsi tahun 2010 maka kedua kondisi menjadi pertimbangan dalam pemilihan warga dusun Kalitengahkidul sebagai obyek penelitian.

Paradigma penelitian yang digunakan adalah post-positivist dengan pengumpulan data kuantitatif sebagai data utama dan data kualitatif sebagai data pendukung (Creswell,201:53) . Pengumpulan data kuantitatif digunakan untuk memperoleh analisis terhadap tiga jaringan komunikasi pada fase kesiapsiagaan menghadapi bencana alam erupsi Merapi tahun 2010. Pertama, jaringan komunikasi mengenai status gunung (normal, siaga, awas, waspada). Kedua, jaringan komunikasi tentang tanda-tanda visual bahaya aktivitas gunung berupa asap, gemuruh, letusan dsb. Ketiga, jaringan komunikasi tentang kapan waktu mengungsi.

Analisis jaringan komunikasi digunakan untuk memperoleh gambaran mengenai relasi 176 warga dusun yang memiliki kriteria sebagai responden. Jaringan komunikasi akan memberikan gambaran bagaimana relasi para aktor dalam jaringan serta siapa saja pihak yang paling banyak dihubungi oleh aktoraktor pada fase kesiapsiagaan menghadapi bencana erupsi. Untuk memperdalam analisis jaringan komunikasi serta interpretasi dilakukan wawancara terhadap enam orang yang terdiri dari lurah, kepala dusun, beberapa relawan dan warga desa. Pertanyaan wawancara yang diajukan seputar hal-hal yang terkait dengan upaya saat kesiapsiagaan menghadapi erupsi 2010, mengapa hanya aktor-aktor tertentu yang dihubungi untuk memperoleh informasi, bagaimana pesan tentang resiko bencana disampaikan, serta bagaimana umumnya sikap warga dusun tentang informasi mengenai kesiapsiagaan menghadapi bencana erupsi. Peristiwa bencana erupsi tahun 2010 meskipun sudah beberapa tahun berlalu namun merupakan pengalaman yang meninggalkan trauma sehingga informan masih dengan mudah mengingat saat terjadinya peristiwa tersebut.

\section{Hasil Penelitian dan Pembahasan}

Hasil penelitian ini terbagi menjadi dua bagian. Pertama adalah tiga jaringan komunikasi yang terdiri dari gambar jaringan berikut penjelasan mengenai aktor yang berada pada posisi sentral jaringan. Pada bagian kedua adalah analisis mengenai 
modal sosial yang terbentuk di masyarakat. Pada bagian diskusi dilakukan intepretasi timbal balik apa yang diperoleh dari modal sosial yang dimiliki masyarakat.

\section{Jaringan Komunikasi pada Fase Kesiapsiagaan Bencana}

Fase kesiapsiagaan pada bencana erupsi Merapi tahun 2010 berlangsung sekitar hingga dua bulan Saat itu merupakan fase saat terjadinya peningkatan aktivitas vulkanik gunung seperti kepulan asap, gempa dan suara gemuruh yang berlangsung antara satu hingga dua bulan sebelum erupsi puncak. Pada fase ini pemerintah setempat sudah memberikan peringatan kepada warga untuk tidak mendekati wilayah puncak serta menghindari aktivitas disekitar puncak yang sewaktu-waktu bisa menimbulkan erupsi dan mengeluarkan awan panas. Namun demikian warga dusun mengandalkan peristiwa pada erupsi tahun
2006 dimana Merapi tidak mengalami erupsi puncak sehingga tidak mengungsi. Warga dusun lebih banyak mengandalkan pengamatan visual dan cenderung mengabaikan peringatan resmi pemerintah. Namun demikian mendekati akhir Oktober 2010 dimana aktivitas vulkanik semakin meningkat maka terjadi perubahan sikap warga dusun yang memerlukan informasi untuk kesiapsiagaan menghadapi bencana. Berikut analisis ketiga jaringan komunikasi yang masing-masing terdiri dari gambar jaringan komunikasi dengan analisis mengenai gambar jaringan komunikasi serta deskripsi tentang aktor-aktor yang menduduki posisi sentral.

Pada fase kesiapsiagaan bencana mengenai status gunung (normal, siaga, awas, waspada) maka status gunung diumumkan secara resmi dari BPPTK melalui kepala dusun dan relawan bencana diteruskan kepada
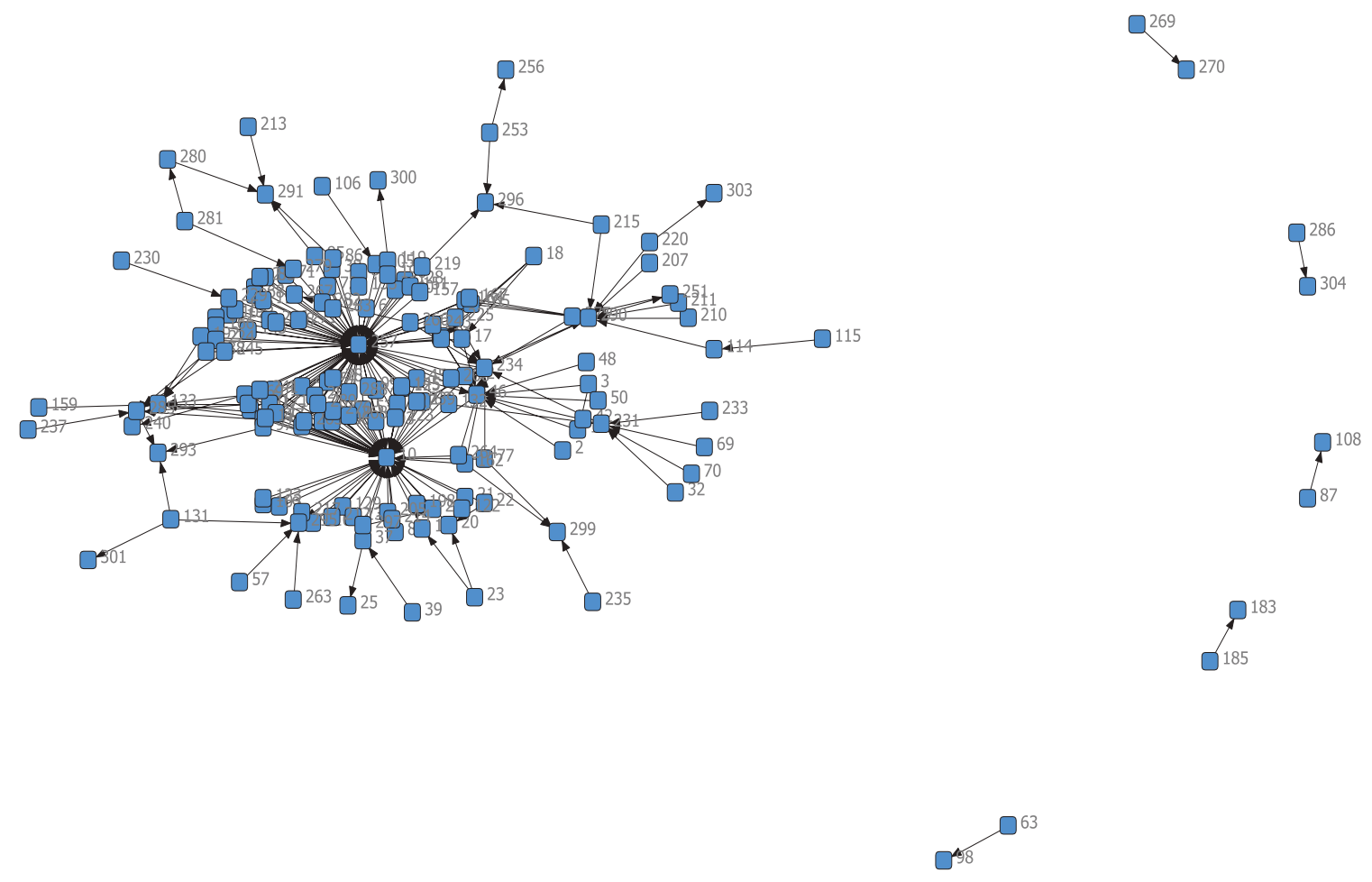

Gambar 1. Jaringan komunikasi mengenai status gunung (normal, siaga, awas, waspada) 
warga dusun. Pada gambar jaringan dan dari hasil perhitungan diperoleh beberapa aktor yang menduduki posisi sentral diantara aktor lainnya. Hanya sepuluh aktor yang terpisah dari aktor-aktor yang memiliki relasi dengan aktor di posisi sentral namun sepuluh aktor yang terpisah tersebut masing-masing berada dalam satu komponen berelasi dengan minimal satu aktor lain. Artinya tidak ditemukan aktor yang terisolasi dari jaringan. Tempat tinggal warga dusun berada di lereng gunung dan diantaranya lokasi tempat tinggalnya terpisah dari warga lainnya. Sebagian besar masih mengandalkan alat komunikasi tradisional kentongan. Penggunaan handphone tidak menjadi andalan warga dusun karena dianggap tidak efektif karena kelemahan dalam mengkases jaringan sinyal dan pembelian pulsa.

Status gunung pada fase ini yang mengalami peningkatan aktivitas diamati warga dari munculnya asap, awan panas, gemuruh, dan suara letusan. Warga dusun umumnya masih measa aman dan masih beraktifitas bertani sayur saat muncul asap dan suara gemuruh. Namun ketika awan panas sudah mulai meluncur maka warga dihimbau untuk segera mengungsi karena diperkirakan dalam hitungan jam akan muncul letusan. Dari gambar jaringan dan perhitungan menunjukkan terdapat sekitar duapuluhan aktor yang terpisah dari jaringan namun terikat dalam komponen sehingga tidak ada yang terisolasi. Gambar memperlihatkan bahwa setiap aktor memerlukan informasi dari aktor lainnya tentang tanda-tanda visual aktivitas gunung untuk memastikan tindakan apa yang harus diambil. Beberapa aktor menjadi tokoh sentral yang paling sering dihubungi oleh sebagian besar aktor-aktor lainnya.

Pada situasi dimana terjadi peningkatan aktivitas vulkanik yang lebih tinggi maka

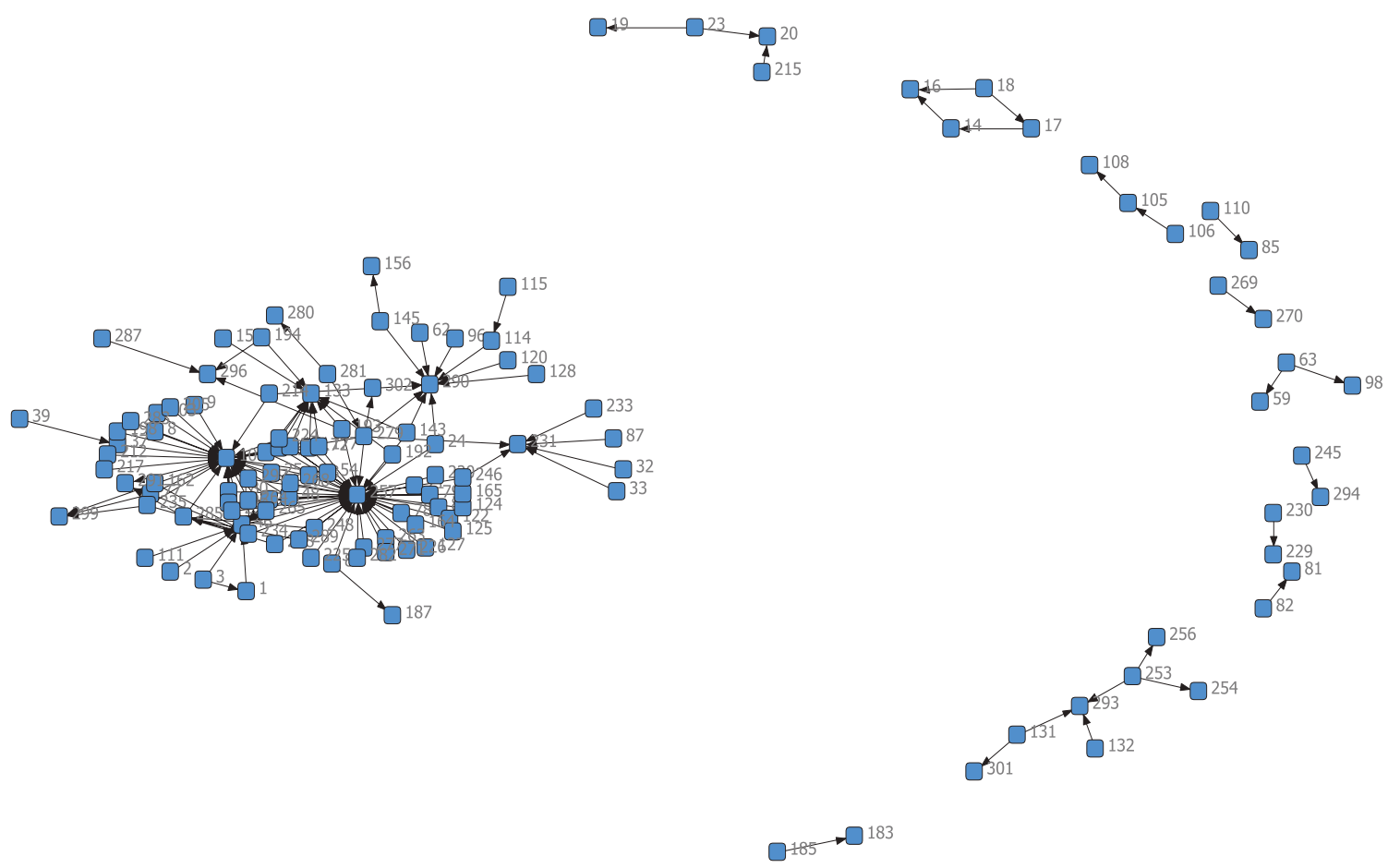

Gambar 2. Jarıngan komunıkası tentang tanda-tanda visual bahaya aktıvitas gunung (asap, awan panas, gemuruh, letusan dsb) 


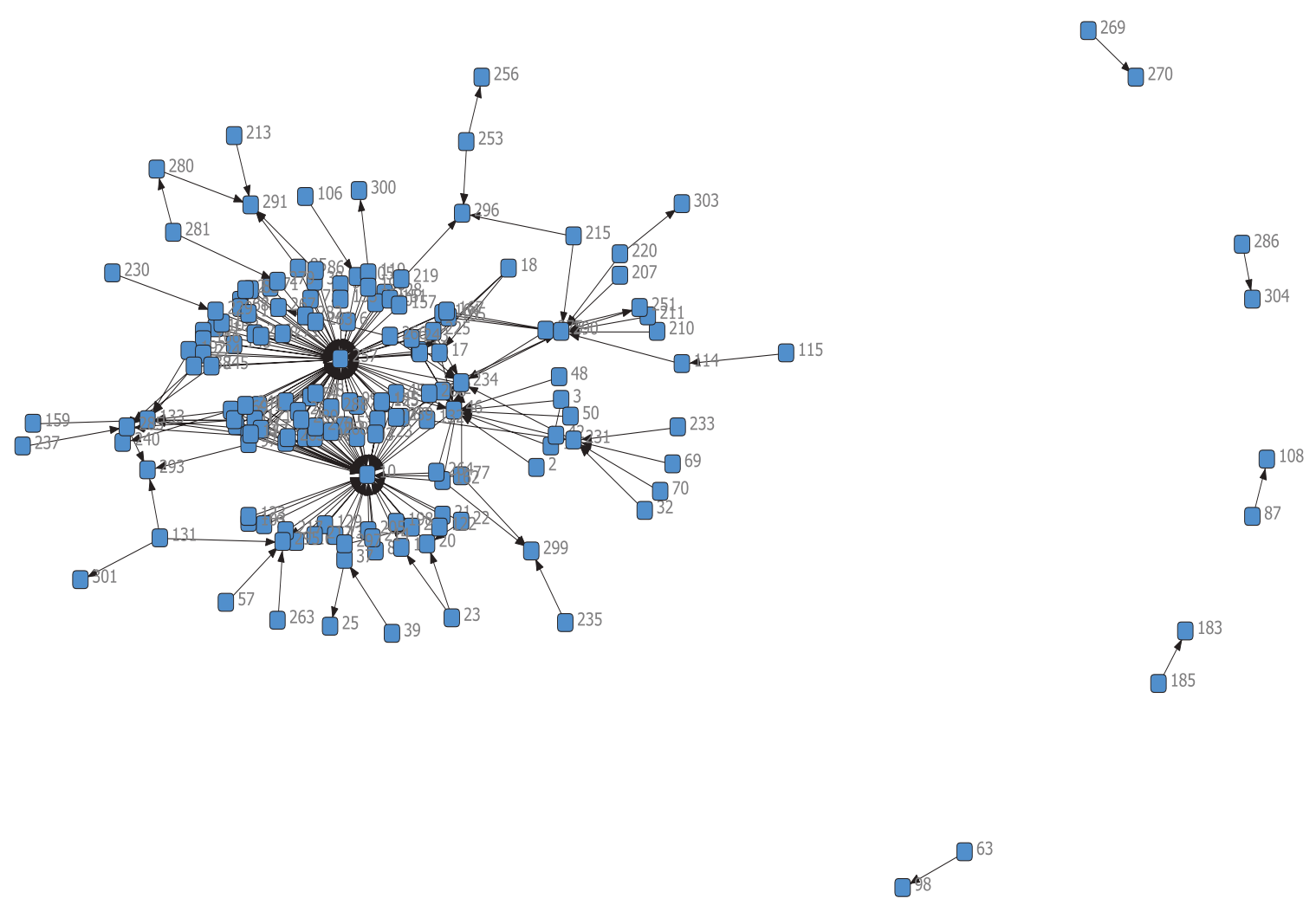

Gambar 3. Jaringan komunikasi tentang kapan waktu mengungsi

dan terlihat tanda-tanda erupsi aktor-aktor berusaha memperoleh informasi mengenai dimana saja lokasi yang disediakan sebagai tempat pengungsian. Terdapat beberapa lokasi yang disediakan pemerintah lokal untuk menampung warga yang mengungsi bersama warga dari dusun-dusun lainnya. Lokasi yang disiapkan untuk menampung pengungsi antara 10 hingga 20 kilometer dari lokasi dusun tempat tinggal warga. Terdapat enam aktor yang tidak berelasi atau terpisah dengan jaringan yang dekat dengan aktor sentral, namun namun masingmasing aktor terikat dalam komponen dengan satu aktor lainnya. Informasi mengenai lokasi pengungsian amat penting bagi hampir seluruh aktor sehingga banyak aktor berupaya menghubungi aktor-aktor di posisi sentral. Ketergantungan hampir semua aktor pada aktor-aktor lainnya nampak tinggi pada fase ini karena terjadi pada waktu yang sangat pendek hanya dalam beberapa hari, bersamaan dengan ribuan penduduk dusun lain harus meninggalkan dusunnya sambil berusaha memperoleh bantuan untuk mengungsi yang jumlahnya sangat terbatas. Warga dusun tidak mengira akan terjadi erupsi besar sehingga tidak pernah membayangkan bahwa mereka harus mengungsi.

Analisis berikutnya adalah tentang siapa saja aktor-aktor pada posisi sentral yang terdapat dalam jaringan komunikasi. Aktor pada posisi sentral dalam jaringan komunikasi adalah aktor yang paling sering dihubungi oleh aktor lain dan memiliki akses terhadap informasi serta sumberdaya dibanding aktor lainnya. 
Tabel 2 : Aktor-aktor pada posisi sentral dalam jaringan komunikasi

\begin{tabular}{ll}
\hline \multicolumn{1}{c}{ Jaringan Komunikasi } & \multicolumn{1}{c}{ Nama Aktor } \\
\hline $\begin{array}{l}\text { Status aktivitas gunung (Normal, Siaga, Waspada, } \\
\text { Awas) }\end{array}$ & Suroto (lurah), Pandi Wiyono (warga), Endang S (warga), \\
& Sarjono (warga), Sugiyanto (RT), Ripto Wiyono (warga), \\
& $\begin{array}{l}\text { Suyono (warga), Ngatiyem (warga), Slamet Tikto (warga), } \\
\text { Jemiyo (RT) }\end{array}$ \\
\hline Tanda-tanda visual aktivitas bahaya gunung & Slamet Tikto (warga), Nugraheni (warga), Ninik (warga), \\
& Mitro W (warga), Indah (warga), Warno (warga), Susanti \\
& (warga), Paiyem (warga), Eko Riswanto (warga), Karyo \\
& (warga), Jamin (kadus), Suroto (lurah), Relawan, Wakidi \\
& (ketua RT), Sugiyanto (ketua RT), BPPTK, Tim Sar, LSM \\
\hline Kapan waktu mengungsi & Jamin (kadus), Suroto (lurah), Sarjono, relawan, Wakidi (ketua \\
& RT), Sugiyono (ketua RT), Sugiyanto (ketua RT), Jemiyo (ketua \\
& RT), BPBD, Pemda, Maryono (warga), Susanti (warga), Marni \\
(warga), Wakidi (Ketua RT), Ninik (warga), Ny.Karyo (warga),
\end{tabular}

Sumber: Data diolah

Dari hasil perhitungan sentralitas jaringan komunikasi dan wawancara ditemukan bahwa sentralitas aktor pada ketiga jaringan komunikasi cukup menyebar atau terdesentralisasi. Artinya posisi sentral berada pada banyak orang bukan hanya pada beberapa orang saja. Terdapat minuml sepuluh orang yang menduduki posisi sentral. Selanjutnya jika melihat dari posisi aktor yang menjadi sentral informasi pada setiap jaringan komunikasi ditemukan aktor lebih banyak merupakan warga dusun biasa, pada urutan terbanyak kedua adalah orang-orang yang memiliki posisi di struktur sosial dusun (lurah, kepala dusun dan ketua rukun tetangga), sedangkan berikutnya adalah adalah orang-orang yang bukan merupakan warga dusun (relawan, tim SAR, Pemda, BPBD, LSM, BPPTK). Aktor tidak dapat menyebutkan nama untuk orang-orang yang berasal dari luar dusun namun hanya dapat mengingat nama organisasi yang menaungi. Karena jumlah aktor yang cukup banyak dan bergantian mendatangi aktor untuk menyampaikan informasi tentang kesiapsiagaan menghadapi bencana erupsi.

Jumlah aktor yang berada pada posisi sentral dan cukup menyebar ini cukup baik mengingat wilayah dusun yang berada di lereng gunung dan warga tinggal secara berkelompok. Penyebaran aktor sebagai sumber informasi menggambarkan bahwa informasi yang diperoleh aktor-aktor dalam jaringan komunikasi mudah untuk diakses, tidak terpusat hanya pada aktoraktor tertentu saja, dan aktor memperoleh informasi dari berbagai sumber bukan hanya dari warga lokal.

Dari hasil analisis mengenai jaringan komunikasi tentang aktor-aktor pada posisi sentral selanjutnya dilakukan analisis terhadap dari perspektif modal sosial khususnya modal. Selain modal sosial eksklusif atau yang mengikat seperti hubungan keluarga, kelompok kekerabatan dan kelompok sosial lainnya ditemukan modal sosial inklusif yaitu aktor-aktor yang bukan berasal dari warga dusun yang terlibat pada fase kesiapsiagaan menghadapi bencana erupsi. 
Modal Sosial Inklusif dalam Jaringan Komunikasi pada Fase Kesiapsiagaan Bencana

Penelitian ini menemukan beberapa modal sosial inklusif yang terdapat di masyarakat lokal yang dapat mendukung proses mitigasi bencana yaitu relasi aktor dengan para relawan bencana, relasi dengan pemerintah daerah, relasi dengan lembaga swadaya masyarakat, dan relasi tradisional dengan keraton Yogyakarta.

a. Relasi dengan relawan bencana, tim SAR dan LSM

Relawan bencana dan tim SAR yang terdapat di wilayah ini terdapat beberapa kelompok. Diantaranya adalah kelompok Induk Bale Rante yang anggotanya terdiri dari gabungan antara relawan lokal dan dari luar wilayah Kabupaten Sleman. Kehadiran relawan bencana dan Tim SAR yang jumlahnya ratusan orang terutama pada fase kesiapsiagaan memberikan informasi baru bagi warga lokal tentang penanganan bencana berikut aktivitasnya. Pertama, relawan bencana melakukan pemantauan aktivitas gunung dengan menggunakan teknologi perangkat pemancar yang hasilnya dapat diketahui dengan cepat dan divisualisasikan sehingga warga lokal juga memperoleh edukasi dalam hal pengamatan aktivitas vulkanik dengan menggunakan pengetahuan modern. Selama ini dalam mengamati aktivitas vulkanik gunung Merapi (asap, awan panas, getaran tanah, suara gemuruh dsb) warga lokal lebih mengandalkan pengamatan visual langsung dan pengetahuan tradisional yang diperoleh secara turun-temurun. Dengan tambahan informasi baru dari relawan yang menggunakan teknologi modern maka pengamatan terhadap aktivitas vulkanik dapat dilakukan dengan lebih akurat dan dapat diambil tindakan lebih cepat dan tepat. Kedua, relawan bencana membantu memberikan penjelasan dan bantuan evakuasi ternak lebih dini kepada warga. Karena ternak merupakan asset yang penting bagi warga maka warga perlu disadarkan agar melakukan perlindungan assetnya dari resiko bencana erupsi. Ternak merupakan aset warga untuk diperah susunya dan dijual saat tidak produktif lagi. Namun demikian warga dusun enggan menyerahkan ternaknya karena yakin tidak akan terjadi erupsi puncak dan menganggap akan timbul kesulitan dalam pemeliharaan ternak dilokasi lain.

Kepercayaan warga yang cenderung pasrah menerima bencana Merapi menyebabkan warga kehilangan banyak asset yang berharga yang telah dikumpulkan bertahun-tahun sehingga setelah terjadi bencana harus memulai lagi untuk memperoleh asset sebagai modal membangun ekonomi keluarga. Adapun tim SAR dan LSM membantu menawarkan bantuan untuk evakuasi warga dusun.

\section{b. Relasi dengan pemerintah}

Relasi berikutnya yang merupakan modal sosial inklusif adalah relasi aktor dengan elemen pemerintah yaitu pemerintah daerah, pemerintah propinsi, BPPTK (Badan Pengelola dan Pengendali Teknologi Kebencanaan), BPBD (Badan Penanggulangan Bencana Derah, Dinas Kesehatan). Pada fase kesiapsiagaan bencana warga lokal membutuhkan informasi yang 
akurat mengenai status gunung berikut tindakan apa yang harus diambil. Informasi dari pemerintah yang disampaikan secara berjenjang hingga kepala dusun membantu warga untuk menentukan kapan waktu mengungsi, kapan harus mengungsi, melalui jalur mana saja yang aman untuk dilalui dan kemana lokasi pengungsian yang harus dituju serta informasi lain yang diperluksn pada fase kesiapsiagaan. Pemerintah dan lembaga resmi lainnya yang memiliki sumberdaya teknologi modern menyampaikan informasi keada warga dusun melalui lurah, kepala dusun, relawan dan sebagainya.

c. Relasi dengan Keraton Yogyakarta.

Hubungan masyarakat Yogyakarta dengan Keraton Yogyakarta hingga saat ini cukup dekat. Rakyat Yogyakarta dan sekitar Merapi mengakui kepemimpinan Sri Sultan Hamengkubowono hingga generasi Sultan yang sekarang (HB $\mathrm{X})$. Merapi selalu dikaitkan dengan Kesultanan Yogyakarta sejak ratusan tahun yang lalu, baik dari segi filosofi, sejarah terjadinya Merapi, pembangunan Keraton Yogyakarta, lokasi Geografis yang terhubung dalam satu garis imajiner antara Merapi di Utara, Laut Selatan di wilayah Selatan dan Keraton Yogyakarta yang barada diantaranya.Berbagai upacara yang harus dilakukan oleh "penjaga" Merapi sebagai wakil kesultanan Yogyakarta dan masyarakat disekitar Merapi, hingga peristiwa aktivitas vulkanik Merapi yang dikaitkan dengan pemerintahan atau politik kesultanan maupun pemerintah Indonesia. Disatu sisi relasi antara masyarakat Merapi (meliputi sekitar 360 desa) dengan keraton Yogyakarta dapat dianggap sebagai peneguhan kekuasaan Sultan terhadap rakyatnya. Meskipun Sultan sebagai raja yang telah berganti beberapa generasi, namun hingga saat ini kepercayaan warga disekitar Merapi dan Yogyakarta pada umumnya masih berlaku dan dipercaya baik dari segi mitos, budaya maupun pemerintahan. Meskipun terdapat sedikit perbedaan sikap dalam memandang merapi pada periode Sri Sultan Hamengkubawono $\mathrm{X}$ (yang memerintah saat ini) dan Sri Sultan Hamengkubuwono IX pada periode sebelumnya, namun kepercayaan warga lokal terhadap relasi antara Merapi dan Kesultanan Yogyakarta masih cukup kuat.

Diantara kepercayaan masyarakat lokal terhadap perintah Keraton Yogyakarta adalah dilaksanakanannya ritual labuhan Merapi. Setiap tahun dilaksanakan kegiatan ritual Labuhan Merapi yang bertujuan untuk memperoleh keselamatan dan terhindar dari bencana letusan gunung Merapi. Ritual labuhan merapi ini sudah dilakukan sejak ratusan tahun yang lalu sebagai bagian dari perintah keraton Yogyakarta. Sebelumnya ritual ini dilaksanakan oleh warga di setiap dusun disekitar Merapi dengan memberikan persembahan berupa berbagai jenis makanan yang dibawa kepuncak Merapi secara bersama-sama dengan warga dari dusun lainnya. Namun dalam beberapa tahun ini ritual tradisional labuhan Merapi dilaksanakan secara kolektif antara beberapa kecamatan disekitar Merapi.

Pada fase kesiapsiagaan menghadapi erupsi 2010 yang lalu Sri Sultan HB X 
telah sejak awal memerintahkan warga dusun untuk meninggalkan wilayah Merapi, namun demikian warga dusun tetap bertahan hingga detik-detik saat terjadinya erupsi. Sikap Sultan yang rasional dalam menghadapi ancaman erupsi Merapi rupanya tidak diindahkan oleh warga dusun yang masih mengandalkan kepercayaan tradisionalnya bahwa Merapi tidak akan terjadi erupsi. Sehingga hal ini sempat menimbulkan pro dan kontra dalam proses evakuasi warga dusun.

Modal sosial inklusif yang ditemukan dalam jaringan komunikasi pada penelitian ini dapat disebut sebagai masyarakat tradisional yang dikenal dengan "mechanical solidarity" yang memperlihatkan adanya perbedaanperbedaan individu yang diminimalisisasi. Solidaritas mekanik merupakan bentuk solidaritas yang mengikat individunya dalam sebuah kelompok sosial karena adanya rasa kebersamaan, adanya aturan untuk berkelompok tanpa mempedulikan status sosial dari individu-individu yang ada dalam komunitas yang bersangkutan. Biasanya solidaritas mekanik terdapat pada masyarakat yang tinggal di pedesaan. Modal sosial inklusif yang terdapat pada jaringan komunikasi pada fase kesiapsiagaan bencana dalam pandangan penulis disebabkan oleh beberapa faktor. Pertama, karena lokasi geografis wilayah yang dekat dengan ibukota pemerintahan sehingga sangat memungkinkan terbentuknya relasi warga dusun dengan instansi pemerintah serta kelompok relawan dari berbagai unsur masyarakat. Kedua, keterbukaan warga terhadap hadirnya pihak luar seperti relawan dan berbagai lembaga masyarakat yang membantu warga sejak fase kesiapsiagaan bahkan berlanjut hingga pasca bencana. Ketiga, bergesernya kepercayaan sebagian warga terhadap kepercayaan tradisional tentang gunung Merapi yang memberikan peluang bagi masuknya informasi baru yang dibawa oleh relasi dengan orangorag yang merupakan modal sosial inklusif tentang mitigasi bencana.

Selanjutnya dari keempat modal sosial inklusif yang ditemukan, terdapat timbal balik yang diperoleh masyarakat lokal dari berbagai jenis modal inklusif yang dimiliki. Pertama, modal sosial inklusif dapat memfasilitasi aliran informasi. Relawan, Lembaga Masyarakat selain berperan dalam menyampaikan informasi baru kepada warga lokal, juga berfungsi menjembatani aliran informasi dari warga lokal ke warga diluar dusun maupun masyarakat lain yang memerlukan informasi guna mengefektifkan bantuan pada fase kesiapsiagaan yang berlangsung lebih dari satu bulan. Kedua, modal sosial inklusif dapat mempengaruhi agen yang memiliki pengaruh penting dalam pengambilan keputusan. Melalui kedekatan warga lokal dengan dengan para relawan bencana dan dari informasi yang disampaikan oleh relawan tentang aktivitas vulkanik dengan menggunakan teknologi, relawan bencana yang sebagian warga lokal memiliki perubahan sikap dan mengajak warga dusun lain untuk mengungsi lebih awal sebelum terjadi erupsi. Karena diwilayah ini sebagian masyarakatnya masih 
memiliki kepercayaan bahwa Merapi tidak akan mengalami erupsi besar seperti halnya pada tahun 2006, maka pada erupsi tahun 2010 masyarakat juga berharap demikian, sehingga lebih banyak warga yang baru mau mengungsi ketika terjadi erupsi. Ketiga, modal sosial inklusif mendukung kredibilitas individu dalam memperoleh akses sumber daya yang dibutuhkan. Dalam kesiapsiagaan bencana selain informasi yang memadai sumberdaya lainnya yang dibutuhkan adalah alat transportasi, akomodasi di pengungsian berikut sarana pendukungnya, dan tempat hunian sementara yang dapat dipenuhi dengan adanya akses kepada pemerintah daerah maupun propinsi. Melalui modal sosial berupa jaringan dengan relawan, kemitraan dengan pemerintah daerah serta jaringan dengan lembaga masyarakat warga dusun terutama orang-orang pada psosisi struktir sosial memiliki kredibilitas yang dapat digunakan untuk memperoleh sumberdaya dalam rangka proses mitigasi bencana. Keempat, modal sosial inklusif sebagai pembangun identitas dan pengakuan yaitu adanya pengakuan masyarakat terhadap terhadap anggota kelompok relawan bencana yang beranggotakan warga dusun maupun dari luar dusun. Dengan pengakuan identitas terhadap kelompok relawan maka informasi dapat diterima oleh wrga dusun melalui jaringan komunikas. Identitas ini diperlukan karena banyak pihak tang memerlukan mediator untuk memasuki wilayah bencana atau memberikan berbagai bantuan melalui individu atau kelompok yang dapat dipercaya.
Identitas dari modal sosial inklusif juga diperoleh warga dengan melakukan aktivitas ritual seperti Labuhan Merapi sebagai bagian dari rakyat yang mengabdi kepada Keraton Yogyakarta dan mematuhi perintah leluhurnya. Identitas ini juga mendukung pelestarian kepercayaan tradisional termasuk kepercayaan terhadap mitos serta membangun solidaritas sosial diantara warga yang sebagian sudah mengalami pergeseran nilai terutama pada generasi muda.

\section{Simpulan}

Modal sosial inklusifmerupakan modal bagi warga dusun yang menghubungkan dengan orang pada kenalan-kenalan jauh yang bergerak pada lingkaran yang berbeda dengan lingkaran mereka sendiri, membangun identitas yang lebih luas yang lebih banyak dibandingkan meneguhkan pada pengelompokkan yang lebih sempit. Pada penelitian ini dari analisis tiga jaringan komunikasi yang diteliti ditemukan terdapat modal sosial inklusif berupa relasi dengan relawan bencana, tim SAR dan LSM; relasi dengan instansi pemerintah, relasi dengan berbagai lembaga masyarakat serta relasi dengan pihak keraton Yogyakarta. Adapun timbal balik yang diperoleh warga dusun dari modal sosial inklusif adalah pertama, modal sosial inklusif dapat memfasilitasi aliran informasi antara lain informasi yang mengalir dari berbagai instansi resmi kepada warga seperti informasi tentang status gunung yang sedang mengalami erupsi dan informasi dari relawan mengenai tindakan apa saja yang harus dilakukan warga desa saat terjadi erupsi. Kedua, 
modal sosial inklusif dapat mempengaruhi agen yang memiliki pengaruh penting dalam pengambilan keputusan. Dengan adanya relasi dengan instansi pemerintah dan lembaga lainnya maka lurah, dusun dan ketua rukun tetangga serta warga desa lain yang dianggap sebagai rujukan dapat dipengaruhi untuk mengambil keputusan penting dalam kesiapsiagaan bencana. Keputusan tersebut seperti kapan warga harus mengungsi, siapa saja yang menjadi prioritas untuk diungsikan dan berbagai keputusan penting lainnya. Ketiga, modal sosial inklusif dapat memberikan dukungan bagi kredibilitas individu dalam memperoleh akses sumber daya seperti alat tranportasi, lokasi pengungsian, kebutuhan pada saat dipengungsian dan sebagainya. Kelima, modal sosial inklusif berfungsi sebagai sebagai pembangun identitas dan pengakuan. Dengan adanya relasi dengan berbagai pihak diluar lingkaran warga dusun, maka posisi warga dusun yang menjadi korban erupsi memiliki identitas baru sebagai korban erupsi serta memperoleh pengakuan dari pihak luar sebagai pihak yang memerlukan bantuan.

Pada jaringan komunikasi fase kesiapsiagaan bencana belum terdapat relasi antara warga dusun dengan instansi perguruan tinggi yang terdapat disekitar wilayah Kabupaten Sleman. Karena pada fase kesiapsiagaan diperlukan relasi dengan perguruan tinggi guna memperoleh masukan mengenai metode-merode baru dari berbagai disiplin ilmu dalam menghadapi kesiapsiagaan bencana dengan lebih cara yang lebih modern serta efektif.

\section{Daftar Pustaka}

Budiarti, Riskha Tri. (2012). Mengidentifikasi Faktor-faktor Penentu Bagi Kesuksesan Proyek Pengelolaan Bencana :Studi Kasus Pengelolaan PemulihanPemulihan Pascabencana Letusan Gunung Merapi di Indonesia, Program Magister Sains Fakultas Ekonomika dan Bisnis Universitas Gadjah Mada Yogyakarta.

Carter,W.Nick. (2008). Disaster Management : a disaster manager's handbook, Asian Development Bank, Philipines

Coleman, James S. (1998). Social Capital in the Creation of Human Capital, AJS Volume 94 Suplement S95-S120. The University of Chicago

Creswell, John W. (2010). Research Design, Pendekatan Kualitatif, Kuantitaif dan Mixed. California: SAGE Publication.

Eriyanto. (2014). Analisis Jaringan Komunikasi. Jakarta: Prenada.

Field, John. (2011). Modal Sosial. Yogyakarta: Kreasi Wacana.

Fukuyama, Francis. (2014). The Great Disuption, Hakikat Manusia dan Rekonstruksi Tatanan Sosial. Yogyakarta: Kalam

Lawang, Robert M.Z. (2005). Kapital Sosial dalam Perspektif Sosiologik Suatu Pengantar. FISIP UI PRESS

Lestari Puji, Prabawa Agung, Wibawa Arif. (2010). Manajemen Komunikasi Bencana Merapi 2010 pada saat Tanggap Darurat, Jurnal Ilmu Komunikasi, Volume 10, Nomor 2, Agustus 2012.

Lin, Nan, Cook, Karen \& Burt, Ronald S. (2001). Social Capital Theory and Research. New York: Aldine De Gruyter. 
Lin, Nan. (2003). Social Capital, A Theory of Capital Structure in Action. New York: Cambridge University Pers.

Magsino, Sammantha L. (2009). Applications of Social Network Analysis for Building Community Disaster Resilience. Wahington DC: Board on Earth Sciences and Resources Division on Earth and Life Studies The national Academic Press.

Maloney,Erin K and Coppola,Damon P. (2009). Communicating Emergency Preparedness: strategic for creating a disaster resilient. USA: Auerbach Publicationa Taylor \& Francis Group.

Marfai, M Aris, Hadmoko, D Sri \& Triyanti Anisa. (2013). Peran Kearifan Lokal dan Sosial Kapital Masyarakat Dalam Pengurangan Resioko Bencana Dan Pembangunan Kawasan Pesisir Berkelanjutan Integrasi Kajian Lingkungan, Kebencanaan dan Sosial Budaya. Sekolah Pasca Sarjana UGM.

Martin R. Degg Martin and and K. David. (2005). Seismic and Volcanic Hazards in Peru: Changing Attitudes to Disaster Mitigation. The Geographical Journal, Vol. 171, No. 2 (Jun., 2005), pp. 125145 Published by: Wiley on behalf of The Royal Geographical Society with the Institute of British Geographers

Monge, Peter R and Contactor. (2003). Theories of Communication Networks. New York: Oxford University Press.
Ozerdam, dkk. (2006). Disaster Management and Civil Society Relief in Japan, Turkey and India. London: Itauris Co Ltd.

Rogers, Evert M \& Kincaid, D Lawrence. (1981). Communication Networks, New York: Free Press.

Universitas Gadjah Mada. (2012). An Integrated Model for Social-Economic Recovery Post Submission of Nominations to The First RCE Award on EFSD Initiatives United Nations University - IAS.

Valente, Thomas W. (2010). Social Networks and Helath, Models Methods and Applications. New York: Oxford University Press.

Varda Danielle M. Rich. (2008). Social Network Methodology in the Study of Disasters: Issues and Insights Prompted by Post-Katrina Research. Forgette David Banks Noshir Contractor Springer Science+Business Media B.V.

Wardyaningrum, Damayanti. (2016). Jaringan Komunikasi Dalam fase Mitigasi Bencana (Analisis Struktur dan Kekuatan Ikatan Lemah (Weak Ties) pada Jaringan Komunikasi Masyarakat di Wilayah Rawan Bencana Gunung Berapi), (disertasi) Departemen Ilmu Komunikasi Universitas Indonesia, Jakarta.

Undang Undang no 24 tahun 2007 tentang Penanggulangan Bencana 